\title{
The Sensitivity of the PCR Method for Detection of Coxiella burnetii in the Milk Samples
}

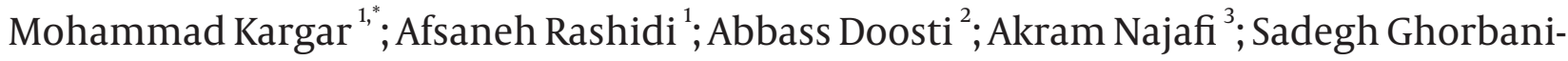 \\ Dalini $^{4}$
}

${ }^{1}$ Department of Microbiology, Jahrom Branch, Islamic Azad University, Jahrom, IR Iran

${ }_{2}^{2}$ Biotechnology Research Center, Shahrekord Branch, Islamic Azad University, Shahrekord, IR Iran

${ }_{3}^{3}$ Persian Gulf Marine Biotechnology Medicine Research Center, Bushehr University of Medical Sciences, Bushehr, IR Iran

${ }^{4}$ Department of Microbiology, Jahrom Branch, Young Researcher's Club, Islamic Azad University, Jahrom, IR Iran

*Corresponding author: Mohammad Kargar, Department of Microbiology, Jahrom Branch, Islamic Azad University, Jahrom, IR Iran. E-mail: mkargar@jia.ac.ir

Received: January 13, 2014; Accepted: April 11, 2014

\begin{abstract}
Background: Coxiella burnetii is an obligate intracellular bacterium that causes the zoonotic disease Q fever with a worldwide distribution. Also C. burnetii is classified as a bioterrorism agent. In order to management, prevention and control of Q fever the fast and accurate detection of $C$. burnetii is necessary. However, the isolation of this strain is very difficult and dangerous.

Objectives: The aim of the study was to evaluate the sensitivity of PCR using different primers for the detection of C. burnetii in milk samples.

Materials and Methods: In this cross-sectional study 70 bovine bulk milk samples were collected randomly from dairy herds in Jahrom, Iran in 2010. All the samples were analyzed for the presence of C. burnetii by PCR targeting 3 different genes (Trans, OMP, Coc). The PCR products were examined by electrophoresis using an agarose gel.

Results: The frequency of C. burnetii in the evaluated samples using Trans-PCR, OMP-PCR and Coc-PCR were $17.14 \%, 10 \%$ and $10 \%$, respectively. Conclusions: The results of this study show that Trans-PCR is highly sensitive and useful for the direct detection of $C$. burnetii in milk samples. This technique is a one-step and fast process in comparison to the other assays.
\end{abstract}

Keywords: Q fever; Coxiella burnetii; Polymerase Chain Reaction (PCR); Bovine milk

\section{Background}

Coxiella burnetii is an obligate intracellular bacterium that causes the zoonotic disease $\mathrm{Q}$ fever with a worldwide distribution. It has a wide range of hosts including mammals such as ruminants, dogs, cats, non-mammal primates, wild rodents, small mammals, big game, and non-mammals such as reptiles, amphibians, birds, fish and ticks $[1,2]$.

Cattle, sheep and goats are the main sources of infection in humans $[3,4]$. Infected animals excrete $C$. burnetii into the environment via birth products such as the placenta. This bacterium is very stable in different environments. It is also highly infectious and one to ten organisms can cause Q fever in humans [5]. Also, C. burnetii can be present in milk, urine, feces, vaginal mucus and semen. In milk, it can be secreted for 8 days in ewes and up to 13 months in cattle [6]. The consumption of contaminated raw milk does not seen to represent an efficient route of disease transmission, however bulk milk samples is an important specimen for epidemiological survey on dairy herds [7]. In order to management, prevention, control and treatment of Q fever in animal and human, early and accurate detection of $C$. burnetii is very necessary. Previous studies on the prevalence of $C$. burnetii in dairy cows were based mainly on serologic tests that detect antibodies that could have been introduced months earlier [8]. Isolation of C. burnetii is very difficult and dangerous. Recently, PCR has been used to detect C. burnetii. PCR is a safe, sensitive and specific method for the detection of $C$. burnetii in different samples [9]. Several target genes that are used for specific $C$. burnetii identification include: the superoxide dismutase (Sod B) gene, com1 encoding a $27 \mathrm{kDa}$ Outer membrane protein, the heat shock operon encoding two heat shock proteins (htpA and htpB), isocitrate dehydrogenase (icd), the macrophage infectivity potentiator protein (cbmip) and a transposon-like repetitive region of the C. burnetii genome (Trans) [10].

\section{Objectives}

Since the clinically healthy cattle are the main source of C. burnetii infection in Iran [11], in the present study, we evaluated the sensitivity of PCR with 3 different primers for detection of $C$. burnetii in bovine bulk milk samples.

Copyright (C) 2015, Zahedan University of Medical Sciences. This is an open-access article distributed under the terms of the Creative Commons Attribution-NonCommercial 4.0 International License (http://creativecommons.org/licenses/by-nc/4.0/) which permits copy and redistribute the material just in noncommercial usages, provided the original work is properly cited. 


\section{Materials and Methods}

In this cross-sectional study 70 bovine bulk milk samples were collected randomly from dairy herds in Jahrom city in the Southern of Iran in 2010. The samples were immediately transported to the laboratory and were tested. One militer of raw milk was centrifuged. This procedure was performed to isolate the bacterial cells in pellet of the milk samples. After removing the cream and milk layers [12], DNA was extracted from the pellet by a genomic DNA purification kit (Cinna Gen Co., Iran) according to the manufacturer's protocol. DNA samples were stored at $-20^{\circ} \mathrm{C}$ until they were used. In this study, we used 8 genomic primers targeting 3 different genes: A) Trans ${ }_{1}$ and Trans $_{2}$ were designed based on the transposing-like repetitive region of the $C$. burnetii genome [13]. The length of the genome target for amplification was expected to be $687 \mathrm{bp}$. B) $\mathrm{OMP}_{1}, \mathrm{OMP}_{2}, \mathrm{OMP}_{3}$ and $\mathrm{OMP}_{4}$ were designed from the nucleotide sequence of the com1 gene encoding a $27 \mathrm{kDa}$ outer Membrane Protein (OMP) as previously described [14]. The expected amplification product of the target sequence with $\mathrm{OMP}_{1}, \mathrm{OMP}_{2}$ was $501 \mathrm{bp}$ long and with $\mathrm{OMP}_{3}, \mathrm{OMP}_{4}$ was 438 bp long. C) The new primers Coc-F and Coc-R were designed based on the 16S rRNA gene in the present study. The length of the predicted product was $242 \mathrm{bp}$.

All oligonucleotide primers were obtained from a commercial source (Cinna Gen Co., Iran). The sequence of the primers is shown in Table 1 . The Trans-PCR thermal program was carried out according to the method described in [9]. The amplification was performed in a total volume of $25 \mu \mathrm{L}$ containing $2 \mu \mathrm{L}$ of DNA sample, $1.5 \mathrm{mM} \mathrm{MgCl}_{2}, 0.2$ $\mathrm{mM}$ (each) dNTPs, $0.2 \mu \mathrm{M}$ primer Trans ${ }_{1}, 0.2 \mu \mathrm{M}$ primer Trans $_{2}$ and $1 \mathrm{U} /$ reaction of Smar Taq DNA polymerase (Cinna Gen Co., Iran). The thermal program was carried out under the following conditions: five cycles of $94^{\circ} \mathrm{C}$ for 30 second, $66-61^{\circ} \mathrm{C}$ (the temperature was decreased by $1^{\circ} \mathrm{C}$ between consecutive steps) for $1 \mathrm{~min}, 72^{\circ} \mathrm{C}$ for $1 \mathrm{~min}$ and then 40 cycles of $94^{\circ} \mathrm{C}$ for $30 \mathrm{~s}, 61^{\circ} \mathrm{C}$ for $30 \mathrm{~s}$ and $72^{\circ} \mathrm{C}$ for $1 \mathrm{~min}$. For the Nested PCR with primers $\mathrm{OMP}_{1}-\mathrm{OMP}_{2}$ and
$\mathrm{OMP}_{3}-\mathrm{OMP}_{4}$, the first amplification was performed in a total volume of $25 \mu \mathrm{L}$, containing $2.5 \mu \mathrm{L}$ of DNA sample, $1.5 \mathrm{mM} \mathrm{MgCl}_{2}, 0.2 \mathrm{mM}$ (each) dNTPs, $1 \mu \mathrm{L}$ primer $\mathrm{OMP}_{1}, 1$ $\mu \mathrm{L}$ primer $\mathrm{OMP}_{2}$, and $2.5 \mathrm{U} /$ reaction of Smar Taq DNA polymerase (Cinna Gen Co., Iran). The PCR assay was done at $94^{\circ} \mathrm{C}$ for $4 \mathrm{~min}$ and then for 30 cycles of $94^{\circ} \mathrm{C}$ for $1 \mathrm{~min}$, $56^{\circ} \mathrm{C}$ for $1 \mathrm{~min}, 72^{\circ} \mathrm{C}$ for $1 \mathrm{~min}$ and a final extension at $72^{\circ} \mathrm{C}$ for 5 min in a DNA thermal cycler. In the second amplification, the reaction mixture was the same as that in the first amplification, except for primers and DNA templates. In this amplification, primers $\mathrm{OMP}_{3} \mathrm{OMP}_{4}$ were used and the first amplification product was used as the DNA template. The PCR assay was performed at $95^{\circ} \mathrm{C}$ for $4 \mathrm{~min}$ and then for 30 cycles of $94^{\circ} \mathrm{C}$ for $1 \mathrm{~min}, 57^{\circ} \mathrm{C}$ for $1 \mathrm{~min}, 72^{\circ} \mathrm{C}$ for $1 \mathrm{~min}$ and a final extension at $72^{\circ} \mathrm{C}$ for $5 \mathrm{~min}$. For the semi nested PCR with primers Coc-F and Coc-R, the amplification was performed in a total volume of $25 \mu \mathrm{L}$ containing $2 \mu \mathrm{L}$ of DNA sample, $1.5 \mathrm{mM} \mathrm{MgCl}_{2}, 0.2 \mathrm{mM}$ (each) dNTPs, $0.2 \mu \mathrm{M}$ primer Coc-F, $0.2 \mu \mathrm{M}$ primer Coc-R and $1 \mathrm{U} /$ reaction of Smar Taq DNA polymerase (Cinna Gen, Iran).

The thermal program was carried out under the following conditions: $95^{\circ} \mathrm{C}$ for $5 \mathrm{~min}$ and then for 32 cycles of $94^{\circ} \mathrm{C}$ for $1 \mathrm{~min}, 58^{\circ} \mathrm{C}$ for $1 \mathrm{~min}, 72^{\circ} \mathrm{C}$ for $1 \mathrm{~min}$ and a final extension at $72^{\circ} \mathrm{C}$ for $5 \mathrm{~min}$. All of PCR reactions were performed in a DNA thermal cycler (Techne). In this study, we used positive and negative controls in each PCR run. C. burnetii DNA (serial Number: 3154; Genekam Biotechnology AG, Duisburg, Germany) was used as the positive control and negative controls were reaction mixtures without a DNA template. Sterile distilled water was used instead of a DNA template. DNA samples of C. burnetii and 5 other bacteria were used in the semi-nested PCR assay in order to evaluate the specificity of new primers Coc-F and Coc-R. The bacteria used in this test were, Staphylococcus aureus, Escherichia coli, Brucella abortus, Brucella melitensis, and Listeria monocytogenes. The PCR-amplification products

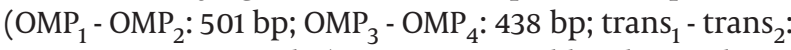
687 ; $\operatorname{Coc}_{\mathrm{F}}-\mathrm{Coc}_{\mathrm{R}}: 242 \mathrm{bp}$ ) were examined by electrophoresis in a $1.5 \%$ agarose gel, visualized under UV and photographed by gel documentation (U GENIUS-SYSGENE).

\begin{tabular}{|c|c|c|c|}
\hline Target Gene & Primers & Primers Sequence & Size (bp) \\
\hline \multicolumn{4}{|l|}{ com1 } \\
\hline & $\mathrm{OMP}_{1}$ & AGT AGA AGC ATC CCA AGC ATT G & 501 \\
\hline & $\mathrm{OMP}_{2}$ & T GAA GCG CAA CAA GAA GAA CAC & 501 \\
\hline & $\mathrm{OMP}_{3}$ & GC CTG CTA GCT GTA ACG ATT G & 438 \\
\hline & $\mathrm{OMP}_{4}$ & TTG GAA GTT ATC ACG CAG TTG & 438 \\
\hline \multirow[t]{3}{*}{ IS1111 } & & & 687 \\
\hline & Trans $_{1}$ & TAT GTA TCC ACC GTA GCC AGT C & \\
\hline & Trans $_{2}$ & CCC AAC AAC ACC TCC TTA TTC & \\
\hline \multirow[t]{3}{*}{ 16S rRNA } & & & 242 \\
\hline & Coc-f & GTA ATA TCC TTG GGC GTT GAC G & \\
\hline & Coc-r & ATC TAC GCA TTT CAC CGC TAC AC & \\
\hline
\end{tabular}




\section{Results}

\subsection{Specificity of Semi-Nested PCR}

In the semi-nested PCR assay with new primers Coc-F and Coc-R only one specific band was observed with the expected size (242 bp) of C. burnetii.

\subsection{PCR}

In total, 7 of 70 tested samples were positive with primers $\mathrm{OMP}_{1}, \mathrm{OMP}_{2}, \mathrm{OMP}_{3}$ and $\mathrm{OMP}_{4}$. The primers $\mathrm{OMP}_{1}$ - $\mathrm{OMP}_{2}$ and $\mathrm{OMP}_{3}-\mathrm{OMP}_{4}$ amplified the predicted products of the 501 bp DNA in the first amplification and the 438 bp DNA in the second amplification of PCR (Figure 1). Also $10 \%$ of samples were positive with primers $\operatorname{Coc}_{F}$ - $\mathrm{Coc}_{\mathrm{R}}$ and showed the $242 \mathrm{bp}$ PCR product on agarose gel (Figure 2). While 12 positive samples were observed with primers Trans - Trans $_{2}$, in amplification with these primers the bands appeared at approximately $687 \mathrm{bp}$, which was in line with the expected length for detection of C. burnetii (Figure 3). The results of the different methods are shown in Table 2.

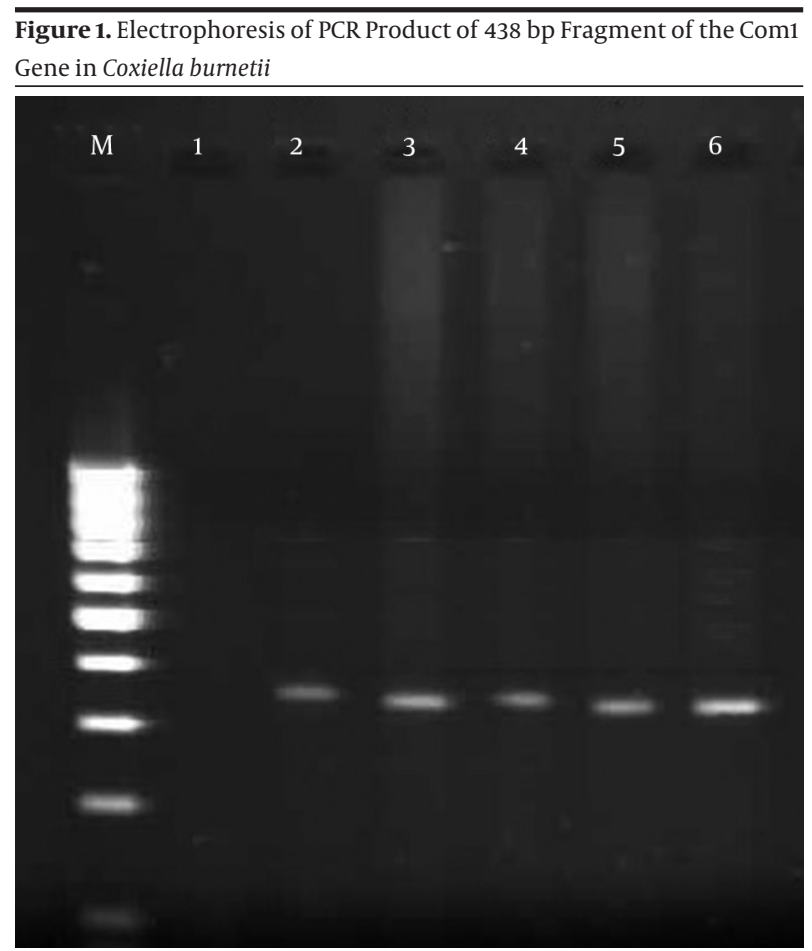

M)100 bp DNA ladder.1) Negative control. 2 -5) Positive samples of Coxiella burnetii. 6) Positive control.
Figure 2. Electrophoresis of PCR Product of $242 \mathrm{bp}$ Fragment of the $16 \mathrm{~S}$ rRNA Gene in Coxiella burnetii

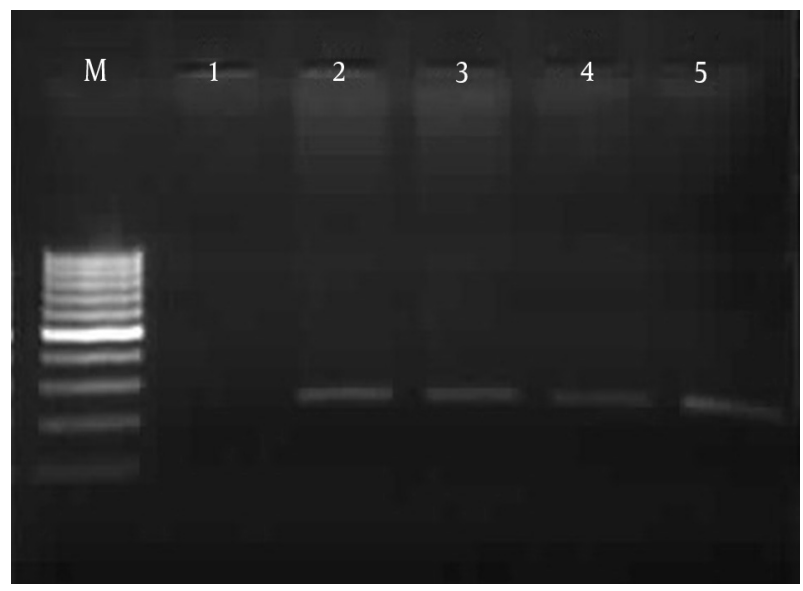

M) 100 bp DNA ladder. 1) Negative control. 2 - 4) Positive samples of Coxiella burnetii. 5) Positive control.

Figure 3. Electrophoresis of PCR Product of 687 bp Fragment of the IS1111 Gene in Coxiella burnetii

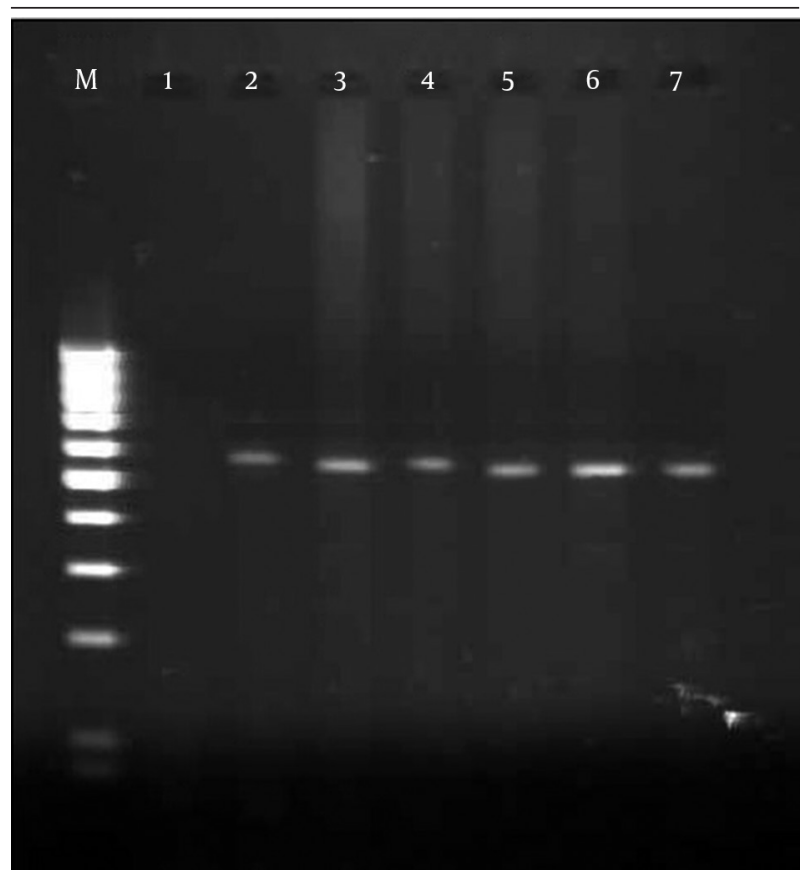

M) 100 bp DNA ladder. 1) Negative control. 2 - 6) Positive samples of Coxiella burnetii.7) Positive control.

Table 2. Sensitivity and Specificity of the Different Methods for Detection of C. burnetti

\begin{tabular}{lccc}
\hline Methods & Numbers of Steps & Numbers of Positive Samples, & Sensitivity \\
\hline Trans-PCR & 1 & $12(17.14)$ & More than other assays \\
OMP-PCR & 2 & $7(10)$ & - \\
Coc-PCR & 2 & $7(10)$ & - \\
\hline In & Acceptable & \\
\hline
\end{tabular}

a In this study the specificity of new primers Coc-f and Coc-r was evaluated and only one specific band was observed with the expected size (242 bp) of C. burnetii. 


\section{Discussion}

In this study we evaluated the sensitivity of PCR with 3 different primers for detection of C. burnetii in bovine bulk milk samples. The Trans-PCR showed more positive samples (17.14\%) while the frequency of C. burnetii by OMPPCR and Coc-PCR in the tested samples was 10\%. This suggests that PCR with primers Trans ${ }_{1}$ and Trans ${ }_{2}$ are highly sensitive and useful for the detection of $C$. burnetii.

Previous studies on the prevalence of $C$. burnetii in dairy bovine were based mainly on serologic tests that detect antibodies that could have been introduced months earlier [8]. Also C. burnetii is classified as a select agent and a CDC (Centers for Disease Control and Prevention) category B bioterrorism agent, with current research on the agent requiring specialized high-containment biosafety level-3 facilities [15]. Recently, PCR have been used to detection of C. burnetii. PCR is usually used for the diagnosis of $\mathrm{Q}$ fever in ruminants in research and clinical works [9]. Although the prevalence of $C$. burnetii is likely to be low in milk, PCR can be used for the detection of C. burnetii in this matrix [13]. Several target genes are used for detection of C. burnetii by PCR. Most of studies have focused on detection and determination of the rate of $C$. burnetii by PCR, while a little information is available about the comparison of different primers.

The purpose of the present study was to evaluate the sensitivity of PCR with 8 different primers targeting 3 genes for the detection of C. burnetii in bulk milk samples. These primers were designed based on different target genes. Com 1 and 16S rRNA are single copy genes while IS1111 is present at multiple copy numbers (7 to 110 copies), depending on the strains of C. burnetii [16]. So it was expected that some of the Trans-positive samples would be negative using the com1 and 165 rRNA assay.

In this test 7 out of 70 milk samples were positive for $C$. burnetii targeting com1 and 16S rRNA. The number of positive samples with Trans-PCR was larger than by any other assay. The use of Trans-primers for the amplification of IS1111 allows the sensitivity of the assay to be increased and this is because of the presence of several copies in the Coxiella genome. Also, Trans-PCR was run in one step whilst nested PCR and semi-nested PCR with other primers were run in two steps. Run of PCR in two steps is time consuming and will increase risk of contamination between two steps. Due to running the PCR in one step and the larger number of positive samples, the Trans-PCR can be more sensitive, reliable, and an easier and faster method for the detection of $C$. burnetii in bulk milk samples. These results are similar to a study in France, which Berri et al. showed Trans-PCR to be very highly specific and sensitive for the direct detection of $C$. burnetii in genital swabs, milk and fecal samples from ewes. Also they pointed that the high degree of efficacy of the trans-PCR can be attributed to the fact that the targeted region exists in at least 19 copies in the C. burnetii Nine Mile, phase I, genome, which gives the trans-PCR a level of sensitivity 100 times higher than that of the PCR assay [9]. In a similar study, Kim et al. in the USA showed the higher sensitivity of Trans-PCR in detection of C. burnetii. Also they reported that the trans-PCR assay detects $C$. burnetii in samples immediately, unlike serologic assays that detect antibodies that could have been introduced months earlier [8]. Vaidya et al. reported that the PCR assay with primers targeting IS1111, the repetitive, transposon-like element (Trans-PCR), is very specific and sensitive for the detection of C. burnetii in clinical samples [17]. In this research the Trans-PCR showed $17.14 \%$ positive samples while the frequency of C. burnetii by OMP-PCR and Coc-PCR in the tested samples was $10 \%$. Since bulk milk samples is an important specimen for epidemiological survey on dairy herds, we evaluated the sensitivity of PCR with 3 different primers for detection of C. burnetii in bovine bulk milk samples. The results of this study suggest that the IS1111 assay is reliably detecting C. burnetii genomic DNA in milk samples and PCR with primers Trans ${ }_{1}$ and Trans ${ }_{2}$ are highly sensitive and useful for the detection of $C$. burnetii. The results of this study are limited to the PCR-based methods for detection of C. burnetii in the bulk milk samples, so we cannot compare the specificity and sensitivity of PCR with other methods such as ELISA. This study suggests that in order to obtain reliable results, the large numbers of samples should be analyzed in subsequent studies. Also it is better to compare different methods for detection of C. burnetii.

\section{Acknowledgements}

The authors are grateful to the Islamic Azad University, Jahrom branch for their executive support of this project. This study was a part of MSc thesis with the number of 8735290 .

\section{Authors' Contributions}

All authors had equal role in design, work, statistical analysis, and manuscript writing.

\section{Funding/Support}

Islamic Azad University, Jahrom.

\section{References}

1. Parker NR, Barralet JH, Bell AM. Q fever. Lancet 2006;367(9511):679-88.

2. Fretz R, Schaeren W, Tanner M, Baumgartner A. Screening of various foodstuffs for occurrence of Coxiella burnetii in Switzerland. Int J Food Microbiol. 2007;116(3):414-8.

3. Psaroulaki A, Hadjichristodoulou C, Loukaides F, Soteriades E, Konstantinidis A, Papastergiou P, et al. Epidemiological study of $\mathrm{Q}$ fever in humans, ruminant animals, and ticks in Cyprus using a geographical information system. Eur J Clin Microbiol Infect Dis. 2006;25(9):576-86.

4. Angelakis E, Raoult D. Q Fever. Vet Microbiol. 2010;140(3-4):297-309.

5. Kersh GJ, Wolfe TM, Fitzpatrick KA, Candee AJ, Oliver LD, Patterson NE, et al. Presence of Coxiella burnetii DNA in the environment of the United States, 2006 to 2008. Appl Environ Microbiol. 2010;76(13):4469-75. 
6. Roest HI, Tilburg JJ, van der Hoek W, Vellema P, van Zijderveld FG, Klaassen $\mathrm{CH}$, et al. The Q fever epidemic in The Netherlands: history, onset, response and reflection. Epidemiol Infect. 2011;139(1):1-12.

7. Vicari N, Faccini S, Ricchi M, Garbarino C, Decastelli L, Boldini $\mathrm{M}$, et al. Occurrence of Coxiella burnetii in bulk tank milk from northwestern Italy. Vet Rec. 2013;172(26):687.

8. Kim SG, Kim EH, Lafferty CJ, Dubovi E. Coxiella burnetii in bulk tank milk samples, United States. Emerg Infect Dis. 2005;11(4):619-21.

9. Berri M, Laroucau K, Rodolakis A. The detection of Coxiella burnetii from ovine genital swabs, milk and fecal samples by the use of a single touchdown polymerase chain reaction. Vet Microbiol. 2000;72(3-4):285-93.

10. World Organization for Animal Health. Manual of diagnostic tests and vaccines for terrestrial animals 2013. 2012. Available from: http:/ www.oie.int/international-standard-setting/terrestrial-manual.

11. Rahimi E, Doosti A, Ameri M, Kabiri E, Sharifian B. Detection of Coxiella burnetii by nested PCR in bulk milk samples from dairy bovine, ovine, and caprine herds in Iran. Zoonoses Public Health. 2010;57(7-8):38-41.

12. Berri M, Arricau-Bouvery N, Rodolakis A. PCR-based detection of coxiella burnetii from clinical samples. In: Sachse K, Frey J editors. PCR detection of microbial pathogens (Methods in Molecular Biology). $1^{\text {th }}$ ed. New Jersey: Humana Press; 2002. pp. 153-61.

13. Hoover TA, Vodkin MH, Williams JC. A Coxiella burnetti repeated DNA element resembling a bacterial insertion sequence. J Bacteriol. 1992;174(17):5540-8.

14. Zhang GQ, Nguyen SV, To H, Ogawa M, Hotta A, Yamaguchi T, et al. Clinical evaluation of a new PCR assay for detection of Coxiella burnetii in human serum samples. J Clin Microbiol. 1998;36(1):77-80.

15. Loftis AD, Priestley RA, Massung RF. Detection of Coxiella burnetii in commercially available raw milk from the United States. Foodborne Pathog Dis. 2010;7(12):1453-6.

16. Klee SR, Tyczka J, Ellerbrok H, Franz T, Linke S, Baljer G, et al. Highly sensitive real-time PCR for specific detection and quantification of Coxiella burnetii. BMC Microbiol. 2006;6:2.

17. Vaidya VM, Malik SV, Kaur S, Kumar S, Barbuddhe SB. Comparison of PCR, immunofluorescence assay, and pathogen isolation for diagnosis of q fever in humans with spontaneous abortions. $J$ Clin Microbiol. 2008;46(6):2038-44. 